\title{
A modest proposal...
}

\section{...for the perfection of nature.}

\section{Vonda N. McIntyre}

The crop grows like endless golden silk. Wave after wave rushes across plains, between mountains, through valleys, in a tsunami of light.

Its harvest is perfection. It fills the nutritional needs of every human being. It adapts to our tongues, creating the taste, texture and satisfaction of comfort food or dessert, crisp vegetables or icy lemonade, sea cucumber or big game. It's the pinnacle of the genetic engineer's art.

It's the last and only living member of the plant kingdom on Earth.

Solar cells cover slopes too steep and peaks too high for the monoculture. The solar arrays flow in long, wide swaths of glass, gleaming with a subtle iridescence, collecting sunlight. Our civilization never runs short of power.

The flood of grain drowns marsh and desert, forest and plain, bird and beast and insect. Land must serve to produce the crop; creatures only nibble and trample and damage it, diverting resources from the service of human beings. Even the immortality of rats and cockroaches has failed.

The grain stops at the ocean's beach. No rivers muddy the sea's surface or break the shoreline. The grain and the cities require fresh water, and divert it before it wastes itself in the sea.

The tides wash up and back, smoothing the clean silver sand, leaving it bare of tangled seaweed, of foraging seabirds or burrowing clams, of the brown organic froth that dirtied it in earlier times. Now and then the waves erase a line of human footprints, but these are very rare.

The air is clear of any bite of iodine, any hint of pollution or decay.

The sea undulates, blue and green, clear as new glass. Sunlight shimmers on its surface and dapples the bare sea floor. Underwater turbines cast shadows on the sand. The tides power the turbines, tapping the force of gravity.

Far from shore, where its colonies will not interrupt the vista of clear water, a single species of cyanobacterium photosynthesizes near the surface, pumping oxygen into the crystalline air, controlling the level of carbon dioxide. Its design copes easily with the increasing saltiness of the sea.

Except for the cyanobacteria, the ocean's cacophony of microscopic organisms has followed redwoods, mammoths and Hallucigenia into extinction. The krill are gone. Krill would be of as little use to people as sharks and seabirds, fish or jellyfish, seashells or whales. They are all gone, too.

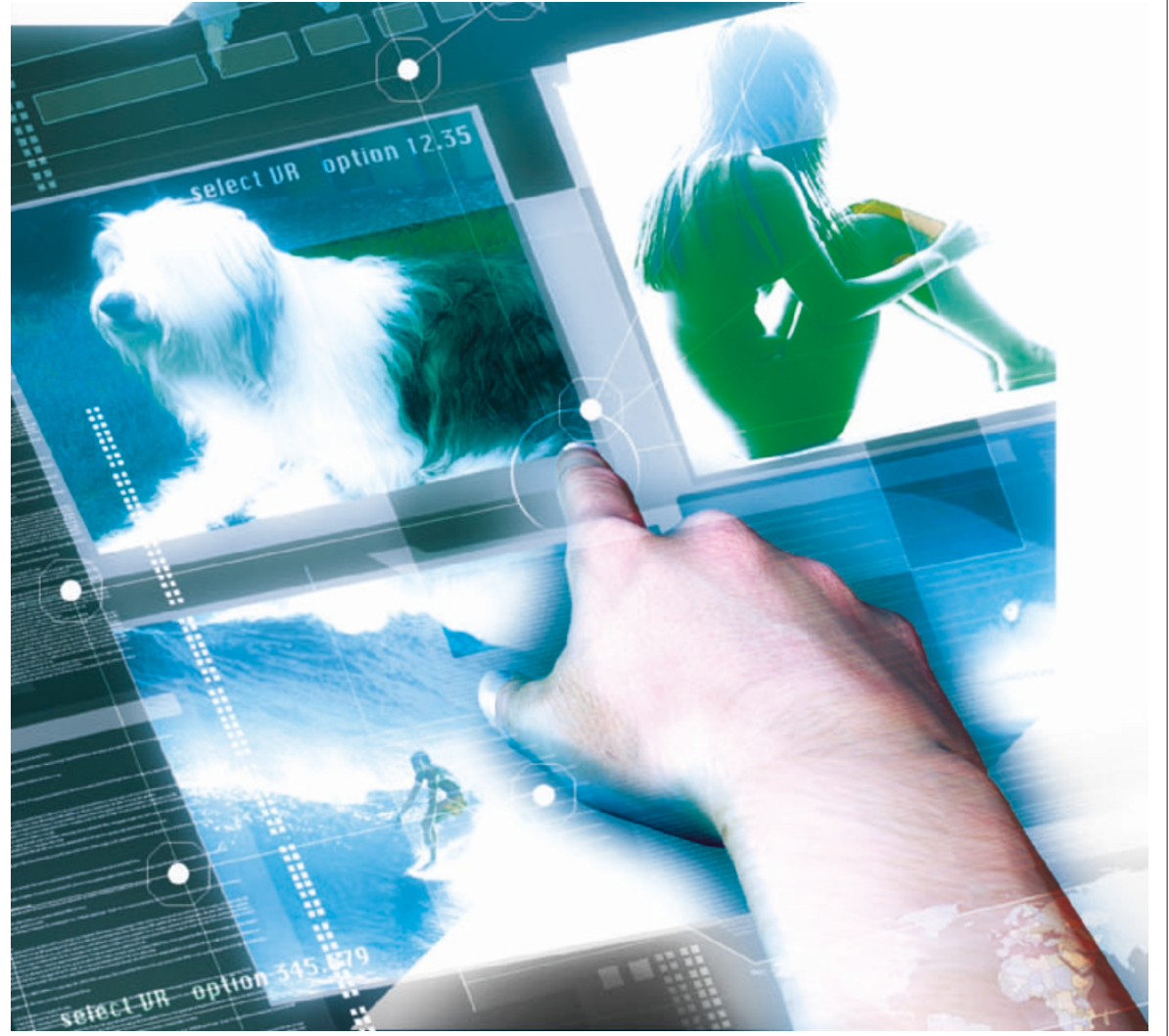

The water deepens beyond the reach of light. The continental shelf ends in a precipice, dropping off into darkness.

On the sea floor, the glass-lace shells of diatoms lie clean and dead, slowly settling. In a moment of geologic time, they will form white limestone.

In the deepest trenches, black smokers gush scalding chemical soup. Machines sense the vents of heat, swim to them, and settle over them to trap the energy from the centre of Earth. Nothing remains for the sustenance and evolution of primordial life in these extraordinary environments.

The strange creatures that lived there, and died, were never any use to human beings.

All the resources of sea and land serve our needs.

Cities of alabaster and adamantine grace the crests of mountains and span the flow of rivers. The cities' people live rich, full lives, long and healthy, free of disease. We are well fed. We have interesting, challenging occupations and plenty of time for leisure, family and virtual reality. We can experience any adventure, from wilderness to exotic ritual, without the expense, trouble or danger of travel. We can experience any adventure that ever happened, any adventure anyone can imagine. The virtual experience matches reality or invention in every way: sight, sound, smell, touch and movement.

Our civilization pulses with vitality. We have unlimited opportunity: of thought, of achievement, of freedom, and of the pursuit of happiness.

Whatever we require, human ingenuity can invent and provide. And if, in some unlikely but imaginable future, we should wish to recreate any organism, the means to do so exist. DNA sequences, RNA sequences, are easy to write down and archive; there is no need to store messy biological material, either tough and persistent DNA or fragile and degradable RNA. We are magnanimous; we have preserved the blueprints for everything, even parasites and pathogens.

No one has bothered to recreate an organism in a very long time. We have considered the question long and hard, and we have made our decision. No creation of nature has an inherent right to exist, independent of our need.

We have perfected nature, for we are its masters.

Vonda N. McIntyre's work runs from Louis XIV (The Moon and the Sun) to space (Little Faces, SciFiction 2005), from local television (producer-director of Science Fiction Conversations) to ancient Crete (The Curve of the World, in progress). Learn more at www.vondanmcintyre.com, www.sfconversations. com and www.scifi.com/scifiction. 